\title{
Read, Mark, Learn and Inwardly Digest: The Prayer Book and Private Devotion in Prayer Book Commentaries from Sparrow to Mant
}

\author{
Benjamin Crosby ${ }^{1}$ \\ Email: benjamin.crosby@mail.mcgill.ca
}

(Received 18 May 2021; revised 2 November 2021; accepted 2 November 2021; first published online 20 January 2022)

\begin{abstract}
Between the Restoration and the rise of the Oxford Movement, a burgeoning literature of commentaries upon the Book of Common Prayer were produced and circulated in England. This article traces the emergence and development of this little-studied commentary tradition in order to explore the role of the Book of Common Prayer in private devotion. It groups the literature into three primary categories based on genre and function: descriptive, historical and biblical commentaries; devotional commentaries; annotated Books of Common Prayer. I argue that this literature sought not only to defend the prayer book from criticism or inform users of its history and function but to encourage devotional engagement with the prayer book itself. Exploring the devotional strategies that this literary tradition teaches and models deepens our understanding of how the leaders of the Church of England during the long eighteenth century sought to encourage private engagement with the Book of Common Prayer.
\end{abstract}

Keywords: Anglicanism, Book of Common Prayer, Church of England, devotion, devotional literature, long eighteenth century, spirituality

The long eighteenth century, lasting from the Restoration of the king, episcopacy, and the Book of Common Prayer to the beginning of the Tractarian movement, has been called the 'golden age of the Book of Common Prayer'. ${ }^{2}$ Over a century of conflict over

\footnotetext{
${ }^{1}$ Benjamin Crosby is a doctoral student in ecclesiastical history at McGill University, School of Religious Studies, Montreal, Quebec, Canada.

${ }^{2}$ Jeremy Gregory, "For all Sorts and Conditions of Men": The Social Life of the Book of Common Prayer during the Long Eighteenth Century: Or, Bringing the History of Religion and Social History Together', Social History 34.1 (2009), pp. 29-54 (32). While the long eighteenth century has traditionally been treated in Anglican historiography as the Church of England's spiritual nadir, a number of recent works have argued compellingly for its vitality. This current study is indebted to them. See, for example, William Gibson, The Church of England 1688-1832: Unity and Accord (London: Routledge, 2001); Donald Spaeth, The Church in an Age of Danger: Parsons and Parishioners, 1660-1740 (Cambridge: Cambridge University Press, 2000); John Walsh,

(C) The Author(s), 2022. Published by Cambridge University Press. This is an Open Access article, distributed under the terms of the Creative Commons Attribution licence (https://creativecommons.org/licenses/by/4.0/), which permits unrestricted re-use, distribution, and reproduction in any medium, provided the original work is properly cited.
} 
liturgy and church government was ended by the 1662 Act of Uniformity. Ministers who were unwilling to swear to the Act of Uniformity, which included conformity to the 1662 Book of Common Prayer, were ejected from their livings. While significant liturgical experimentation happened outside the Established Church, and there were some calls for prayer book reform within it, within the Church of England the Book of Common Prayer came to structure the religious, social, and political lives of its members in a way that it never had before and never would afterwards. The works of Bryan Spinks and Jeremy Gregory have explored the ubiquity of conformity to it in public worship (if not always in every particular), the centrality of its round of services in the religious life of ordinary parishioners, and the loyalty it won from clergy and laypeople alike. ${ }^{3}$ This article builds upon their scholarship to examine the place of the Book of Common Prayer not in the public but in the private religious lives of English Christians over the course of the long eighteenth century, exploring how, as William Jacob put it, worship of the Established Church 'extended beyond public worship into ... household and private devotions. ${ }^{4}$ I will seek to address this question through an exploration of a decidedly understudied genre of literature from the period, the prayer book commentary tradition. ${ }^{5}$

I will sketch out three loose categories into which the bulk of the literature surveyed can be divided: descriptive, historical, and biblical commentaries; devotional commentaries; and annotated Books of Common Prayer. Although not all obviously comprised of devotional material, I will argue that each of these sought to inculcate private spiritual practices around the liturgy in their readers, understood to encompass both clergy and laity. While the first set of commentaries - perhaps the most obvious inheritor of an earlier tradition of prayer book defense - tended not to have pronounced devotional merits of their own, they encouraged a practice of careful study of the liturgy outside of church and frequently sought to encourage a richer devotional life within public worship. A more straightforwardly devotional prayer book commentary tradition, often drawing upon the technique of paraphrase associated especially with Bible commentaries, also emerged. Annotated Books of Common Prayer, a genre which was first developed in the period, typically excerpted the devotional and historical material of longer treatises and printed this

Colin Haydon, and Stephen Taylor (eds.), The Church of England c.1689-c.1833: From Toleration to Tractarianism (Cambridge: Cambridge University Press, 1993).

${ }^{3}$ Bryan Spinks, Liturgy in the Age of Reason: Worship and Sacraments in England and Scotland, 1662c.1800 (Burlington: Ashgate, 2008), especially pp. 1-30; Gregory, 'For all Sorts and Conditions of Men'. See also W.M. Jacob, Lay People and Religion in the Early Eighteenth Century (Cambridge: Cambridge University Press, 1996), pp. 52-92 and, for a slightly more critical reading, Spaeth, The Church in an Age of Danger, pp. 173-94.

${ }^{4}$ Jacob, Lay People and Religion, p. 95.

${ }^{5}$ The fullest study of this literature, C.J. Stranks, Anglican Devotion, pp. 149-73, is over a half-century old, and focuses exclusively on late seventeenth- and early eighteenth-century material. While the work of scholars such as Isabel Rivers have done much to improve our understanding of lived religion and book history in dissenting traditions over the long eighteenth century - see, for example, Isabel Rivers and David Wykes (eds.), Dissenting Praise: Religious Dissent and the Hymn in England and Wales (Oxford: Oxford University Press, 2011) - much work remains to be done on the lived religion of those who conformed to the prayer book and established Church. Jeremy Gregory diagnoses this and calls for scholars to do for the eighteenth century what Judith Maltby's Prayer Book and People in Elizabethan England did for the sixteenth and early seventeenth centuries, exploring 'the relationship between eighteenth century men and women and the Book of Common Prayer'. Gregory, 'For all Sorts and Conditions of Men', p. 31. 
material in the margins of the text of the Book of Common Prayer. I will argue that all these texts sought to inculcate private engagement with the prayer book both to increase devotion in public worship and for use in private prayer, teaching, and demonstrating that the Book of Common Prayer was, as Thomas Comber titled one of his many devotional commentaries on the prayer book, 'A Companion to the Temple and Closet' ${ }^{6}$

\section{Descriptive, Historical, and Biblical Commentaries on the Book of Common Prayer}

Writings on the prayer book did not begin at the Restoration. When, upon the restoration of the liturgy, King Charles II called for a careful instruction in the Book of Common Prayer for an English laity who had largely been without it for the past fifteen years, Church of England divines could draw upon a tradition of prayer book defense stretching back to the Elizabethan Church. ${ }^{7}$ However, in the last years before the Restoration and well into the long eighteenth century, this earlier tradition of prayer book defense was further elaborated by a new set of descriptive, historical, and biblical commentaries on the prayer book. These commentaries sought to defend its use and excellence, establish its continuity with liturgies of the primitive church, and provide detailed explanations of the service to enable laypeople to engage more fully in public worship. While generally not suitable devotional objects in their own right, they did encourage careful private study of the liturgies of the prayer book, sometimes presumed or defended private use of parts of the prayer book, and often explicitly took on the task of explaining the service in a manner which fostered better engagement with public worship.

Two particularly important examples of this genre were published in the last years before the Restoration. Anthony Sparrow's $1659^{8}$ Rationale Upon the Book of Common Prayer and Hamon L'Estrange's 1659 Alliance of Divine Offices both sought to justify the liturgies of the Book of Common Prayer, not only by recourse to familiar arguments about the licitness of set forms of prayer but specifically by comparison of the Book of Common Prayer to the liturgies of the early church as then known. This practice would come to characterize high church Restoration defense of the prayer book. ${ }^{9}$ Sparrow's Rationale goes through the prayer book

\footnotetext{
${ }^{6}$ Thomas Comber, A Companion to the Temple and Closet, or, a Help to Publick and Private Devotion, in an Essay upon the daily Offices of the Church (London: T.R., 1672).

${ }^{7}$ See C.J. Stranks, Anglican Devotion: Studies in the Spiritual Life of the Church of England between the Reformation and the Oxford Movement (Greenwich: Seabury Press, 1961), p. 155. See also Paul Marshall, The Voice of a Stranger: On the Lay Origin of Anglican Liturgics (New York: The Church Hymnal Corporation, 1993), pp. 203-204 and Andrew Braddock, The Role of the Book of Common Prayer in the Formation of Modern Anglican Church Identity: A Study of English Parochial Worship, 1750-1850 (Lewiston: Edwin Mellen Press, 2010), pp. 52-55 for a brief account of earlier defenses of the prayer book.

${ }^{8}$ This is the publishing date given in the Parker Society edition of this work. See Anthony Sparrow, A Rationale Upon the Book of Common Prayer of the Church of England (Oxford: John Henry Parker, 1840), p. ii; Stranks suggests that it might have been first published in 1655 (Anglican Devotion, p. 150).

${ }^{9}$ Braddock, The Role of the Book of Common Prayer, pp. 55-56. This move has an important precedent in Herbert Thorndike's The Service of God; Addleshaw credits Thorndike as 'the first Anglican to explore [early liturgies] systematically'. See G.W.O. Addleshaw, A Study in the Liturgical Thought of the Seventeenth Century (London: Faber and Faber, 1941), p. 33.
} 
service by service, explicating the various parts of each and showing how they are 'agreeable to PRIMITIVE USAGE' and 'A REASONABLE SERVICE'. ${ }^{10}$ Some parts of the prayer book text are quoted over the course of the Rationale, but Sparrow's book does not reflect the practice of annotating the prayer book that we will see in later works. Rather, the first line of a hymn or prayer might be quoted to orient the reader, and Sparrow then goes on to provide explanation and patristic context. ${ }^{11}$ L'Estrange's Alliance of Divine Offices is less of a commentary on the prayer book per se and more an expansive treatment of the history of the development of the English liturgy, compared with known patristic sources. ${ }^{12}$

While neither of these texts are described by their authors as being written with the goal of increasing devotion during worship, they do nonetheless presume detailed engagement with the prayer book; Stranks makes much of the 'devotionally illuminating' character of Sparrow's commentary. ${ }^{13}$ Moreover, both endorse the private use of the daily office by clergy and laity alike when public services are not available. ${ }^{14}$ Sparrow is particularly enthusiastic about this, providing instructions for how to pray the office by oneself and writing that the layperson praying an office alone should know that 'he prays with company, because he prays in the Church's communion, the Common Prayer and vote of the Church'. ${ }^{15}$ Moreover, Sparrow, at least, sees the goal of his text as not only a defense of the prayer book but also as consolation for those persecuted in using it: he hopes that it will 'shew reasons why they should suffer on, and love it still more'. ${ }^{16}$ This is no mere scholarly commentary or even just an entry into a theological debate; Sparrow evidently hopes that his text will inspire devotion to the prayer book itself.

Of course, not all commentaries had this particular patristic focus. In 1610, John Boys published a compilation of all of the verses of the Bible used or referenced in the Book of Common Prayer, ${ }^{17}$ and this desire to establish the Scriptural basis of the prayer book continued to find expression after the Restoration well into the eighteenth century. Thomas Elborow wrote a series of commentaries covering the bulk of the Book of Common Prayer, providing a set of explanations to the various parts of each service which emphasized prayers' scriptural basis. ${ }^{18}$ Strikingly, the goal here is not merely the vindication of the Scriptural nature of the liturgy against its enemies. The Dedicatory Epistle to the 1677 The Reasonableness of our Christian Service (As Contained in the Book of Common-Prayer) Evidenced, written by a friend of Elborow's who had the work published after his death, suggests that the

\footnotetext{
${ }^{10}$ Sparrow, Rationale, p. vi.

${ }^{11}$ See, for example, Sparrow, Rationale, p. 45.

${ }^{12}$ The treatment of the Holy Communion service at Hamon L'Estrange, The Alliance of Divine Offices (Oxford: John Henry Parker, 1846), pp. 224-305 is indicative.

${ }^{13}$ Stranks, Anglican Devotion, p. 153.

${ }^{14}$ Sparrow, Rationale, pp. 308-10; L’Estrange, Alliance of Divine Offices, pp. 108-109.

${ }^{15}$ Sparrow, Rationale, p. 310.

${ }^{16}$ Sparrow, Rationale, p. vi.

${ }^{17}$ John Boys, An Exposition of al the Principal Scriptures Vsed in our English Liturgie Together with a Reason Why the Church Did Chuse the Same (London: Felix Kyngston, 1610).

${ }^{18}$ Thomas Elborow, A Guide to the Humble: Or an Exposition on the Common Prayer (London: Printed for Henry Brome, 1675). Thomas Elborow, The Reasonableness of our Christian Service (As Contained in the Book of Common-Prayer) Evidenced (London, 1677).
} 
commentary was also to give worshippers 'a true Sense of their Publick Devotions' and 'to beget the Worship of God its due reverent performance'. ${ }^{19}$ About a halfcentury later, John Veneer published A New Exposition on the Book of Common Prayer Wherein the Whole Service Is Illustrated and Defended by Incontestable Proofs Drawn from the Holy Scriptures. By this point, the prayer book commentary tradition had been quite well established; Veneer mentions the works of Sparrow as well as Wheatly, Nicholls, and Comber (see below), but differentiates his work from theirs because of his explicitly scriptural focus, which he deems more likely to convince dissenters and please readers. ${ }^{20}$ Unlike Eldorow, Veneer does not connect his work to the promotion of greater devotion per se, although he does call for laypeople to 'bless God for that Excellent and Serious Liturgy', presumably a blessing elicited by a careful reading of Veneer's book! $!^{21}$

A significant transformation of the prayer book commentary genre discussed here is exemplified by Charles Wheatly's A Rational Illustration of the Book of Common Prayer of the Church of England, first published in $1720 .^{22}$ The subtitle indicates precisely what makes this text important: ' ... being the Substance of Every Thing Liturgical in Bishop Sparrow, Mr. L'Estrange, Dr. Comber, Dr. Nichols, and All Former Ritualists, Commentators, and Others, Upon the Same Subject'. ${ }^{23}$ This is a text which situates itself as carrying forward an established tradition of liturgical commentary. In the preface to what seems to be the fourth edition, perhaps nervous about accusations of a lack of originality, Wheatly notes that 'the whole that I borrowed ... does not amount to near a fourth part' of the book as a whole. But in general it is hard to disagree with Stranks that Wheatly, rather than producing new analysis, primarily 'summed up a good deal of what had been done to explain the history and development of the Prayer Book in the previous last century'. ${ }^{24}$ If not particularly novel, Wheatly's work did prove to have a lasting staying power: as Braddock notes, it was 'often recommended for study, appearing in the lists of books produced by bishops for ordinands and priests, as well as in the personal reading lists of the clergy' ${ }^{25}$ More significantly for the purposes of this essay, it also 'was frequently cited in later commentaries on the Prayer Book' ${ }^{26}$

This tradition of descriptive prayer book commentaries did not end with Wheatly and Veneer. Another example, particularly significant in that it appears to be the only prayer book commentary published between the Restoration and the Oxford Movement written by a woman, is Sarah Trimmer's 1791 A Companion to the Book of Common Prayer. Trimmer's book is a painstaking exposition of the Sunday service of the Book of Common Prayer (that is, Morning

\footnotetext{
${ }^{19}$ Elborow, The Reasonableness of our Christian Service, A4.

${ }^{20}$ John Veneer, A New Exposition of the Book of Common Prayer (London: Printed for C. Rivington, 1727), B1-B4.

${ }^{21}$ Veneer, A New Exposition, B9.

${ }^{22}$ Charles Wheatly, A Rational Illustration of the Book of Common Prayer of the Church of England (London: Henry G. Bohn, 1849), title page. See Stranks, Anglican Devotion, p. 161 for the book's publication history.

${ }^{23}$ Wheatly, A Rational Illustration, title page.

${ }^{24}$ Wheatly, A Rational Illustration, p. v; Stranks, Anglican Devotion, p. 161.

${ }^{25}$ Braddock, The Role of the Book of Common Prayer, p. 55.

${ }^{26} \mathrm{Braddock}$, The Role of the Book of Common Prayer, p. 55.
} 
Prayer, Evening Prayer, Prayers and Thanksgiving, the Litany, Holy Communion, and the Epistles and Gospels). Trimmer typically provides the element of the service she is treating, along with any rubrics concerning it, before launching into an explanation of its meaning and how one ought to pray and hear that particular text. Thus, for example, the section on the general confession at morning prayer begins with the rubric preceding it and the first words - 'Almighty and most merciful Father, \&c.' and then moves directly to exposition: 'A general confession is a confession in which all the congregation join ...' ${ }^{27}$ Unlike Wheatly or Sparrow, Trimmer is uninterested in exploring the patristic roots of the liturgy or even in vindicating the liturgy against its opponents; rather, she writes so that 'young persons' may be taught 'how to join properly in the praises, prayers, \&c. composed for the common use of all Christians who profess themselves members of [the Church of England]'. ${ }^{28}$ She is confident that careful study of her collection will 'assist devotion' in those who attend worship services of the church. ${ }^{29}$ J. Clutterbuck's earlier A Plain and Rational Vindication of the Liturgy of the Church of England had a similarly narrowly educative focus; this relatively short work used a question-and-answer format to explain the services and answer objections to them; there is no pretention to great learning but simply an attempt to help people 'understand what they pray for' ${ }^{30}$ However, these works, though doubtless useful to their readers, would play a significantly less important role in the further development of the prayer book commentary tradition than those of Sparrow, L'Estrange, and Wheatly.

These texts, in general, were not conceived of by their authors as devotional texts. Indeed, they not infrequently explicitly eschewed affective rhetoric in favor of historical, logical, and scriptural argument. ${ }^{31}$ Moreover, the aims of most of these texts are largely consonant with earlier defenses of the prayer book: defending set prayers and showing the book's scriptural basis, albeit with an increased focus on grounding the liturgy in patristic evidence and explicating the liturgy. However, the act of reading any one of them would engage the reader in detailed, careful study of the liturgical text, moving liturgy from purely a matter of public worship to private study. Moreover, there are some suggestions, most obviously in Eldorow's and (the significantly later) Trimmer's works, that the texts' authors believed that increased understanding of and affection for the prayer book would shape worshippers' experience of public worship and encourage deeper devotion in public worship. Further, and most crucially for my argument, both Sparrow and L'Estrange endorse the private use of morning and evening prayer, with Sparrow expressing particular enthusiasm about it. The detailed description of the liturgy they provide and their explicit encouragement were both intended to inculcate private devotional use of the prayer book liturgy, at least in those instances where public worship using the prayer book is not available.

\footnotetext{
${ }^{27}$ Sarah Trimmer, A Companion to the Book of Common Prayer of the Church of England (London: Longman, Patterson, and Johnson, 1791), p. 8.

${ }^{28}$ Trimmer, Companion, p. v. Gregory notes the ubiquity of the Book of Common Prayer in the education of English children during this period in 'For All Sorts and Conditions of Men', p. 51.

${ }^{29}$ Trimmer, Companion, p. v.

${ }^{30} \mathrm{~J}$. Clutterbuck, A Plain and Rational Vindication of the Liturgy of the Church of England (London: Nutt, 1716), p. 2.

${ }^{31}$ See Sparrow, Rationale, p. vi.
} 


\section{Devotional Commentaries on the Prayer Book}

The long eighteenth century also saw the emergence of a body of material on the prayer book more clearly devotional in character. It is not that these works were uninterested in historical or scriptural questions or in providing a helpful explanation of the prayer book; Wheatly's use of Thomas Comber, one of the most important 'devotional' prayer book writers, renders moot any attempt to draw a clear-cut distinction between these and the works treated above. However, the texts that I have grouped under this heading use a different set of literary techniques, most importantly the paraphrase, and often explicitly describe their aim as fostering devotion. Indeed, the distinction I draw between more devotional and more critical or historical commentaries on the prayer book was not one foreign to writers of the time. ${ }^{32}$ In these works, authors see stirring up increased devotion as a primary goal of their writing (rather than the historical or scriptural vindication of the prayer book, for example), both in public worship and private prayer. Indeed, they also conceptualize the very reading of their commentaries as a devotional act; the reading of these commentaries themselves becomes a means by which the Book of Common Prayer can be used in private devotion. This line of Thomas Comber's describes the general orientation of these works quite well, capturing not only the emphasis on preparation for public worship but also the commitment to using the liturgy to shape one's life outside of worship: '.. if we desire to pray acceptably, we must study our Petitions before we present them; which not only enlivens our Devotion in the act of it, but makes our Prayers become the rule of our lives'. ${ }^{33}$

The aforementioned Thomas Comber is a very important early author in this mode, who is also one of the most prolix commentators on the Church of England's liturgy. He wrote A Companion to the Temple and Closet in 1672 dealing in particular with morning and evening prayer and followed it with $A$ Companion to the Altar, which provided a form of preparation for receiving the Sacrament, and other volumes going through the rest of the prayer book. Much of this material was then combined and expanded as the mammoth A Companion to the Temple, seven volumes in the nineteenth-century Oxford University Press edition. ${ }^{34} \mathrm{He}$ also produced a shortened (relatively! - the 1702 edition was 464 pages) Short Discourses upon the Whole of the Common-Prayer, while also excerpting pieces of his work for publication in pamphlet form. ${ }^{35}$

\footnotetext{
${ }^{32}$ See, for example, the Preface of Thomas Pruen, An Illustration of the Liturgy of the Church of England (London: Bulmer \& Nichol, 1820), where Pruen distinguishes commentators between those writing 'devotional lucubrations [sic]' and those writing 'critical and Rubrical annotations', although I disagree with Pruen on the categorization of Nicholl's and Bennet's projects.

${ }^{33}$ Comber, A Companion to the Temple and Closet, A7.

${ }^{34}$ The publication history here is complicated, not least because of the shared material between the volumes and the various ways the books were compiled and published. See Rémy Bethmont, 'Promoting Anglican Liturgical Spirituality: Thomas Comber's Companions to the Book of Common Prayer', Revue Française de Civilisation Britannique XXII.1 (2017), pp. 1-12 (2) and Stranks, Anglican Devotion, p. 155.

${ }^{35}$ Thomas Comber, Short Discourses upon the Whole Common-Prayer (London: Printed for Robert Clavell, 1702); For the pamphlets, see, for example, Thomas Comber, 'A Discourse Concerning the Daily Frequenting the Common Prayer' (London: Printed for Charles Brome, 1687); Thomas Comber, 'The Christians Best Exercise: Being an Earnest Invitation to the Frequenting of the Common Prayer' (London: Printed for Randal Taylor, 1690).
} 
This vast body of work follows the same basic model in dealing with the prayer book: introductory material is given when necessary, followed by what Comber calls 'the analysis or division' of the prayer, exhortation, or other liturgical element, in which the piece is painstakingly diagrammed and the logic of its composition explained. ${ }^{36}$ Then, Comber moves on to a 'practical discourse', comprising a line by line, often phrase by phrase elaboration of the meaning of the text, with reference to the Bible and to early church sources where appropriate, albeit with a goal of explanation more than historical or scriptural justification. ${ }^{37}$ Next, Comber provides a paraphrase of the text, with the text itself in capitals interspersed with the paraphrase expanding on it. Thus, for example, a portion of the paraphrase on the confession at Morning Prayer reads as follows:

... O Lord, we now find to our sorrow, that WE HAVE FOLLOWED TOO MUCH and too long after false guides, even THE DEVICES and false principles of our corrupted understandings... ${ }^{38}$

On occasion, an additional meditation pertaining to some of the themes is added. ${ }^{39}$ As this sample of his paraphrase suggests, Comber's exposition was incredibly lengthy; his treatment of the confession at morning prayer stretched for 41 pages in the 1841 Oxford University Press reprint! ${ }^{40}$

Comber unambiguously argued for the use of both the prayer book and his own commentaries upon it in private devotion. Comber, like several of the authors treated above, expected the prayer book (especially daily and evening prayer and the collects) to be used in the private devotional life of his readers, especially when public attendance at daily prayer proved impossible. He provides advice for adapting the prayer book services for private devotion, for example, suggesting that the exhortation between the opening sentences and the confession at daily prayer be modified to be used as a prayer rather than directed to a (nonexistent) congregation. ${ }^{41} \mathrm{He}$ further encourages the private use of the collects in 'ejaculatory prayer' at appropriate occasions, facilitating this use by providing a list of collects by theme. ${ }^{42}$ $\mathrm{He}$ also argues that his commentaries themselves should be used as devotional books. The subtitles of his works announce them as helps to devotion; the Short Discourses, for example, is described as 'designed to Inform the Judgment and Excite the Devotion' of those who use the prayer book daily. ${ }^{43}$ Further, he explicitly refers to the second volume of $A$ Companion to the Temple as a 'book of devotion'. ${ }^{44}$

\footnotetext{
${ }^{36}$ See, for example, Comber's treatment of the Confession at Morning Prayer. Thomas Comber, A Companion to the Temple. I. Of Morning and Evening Prayer (Oxford: University Press, 1841), p. 57.

${ }^{37}$ Thus, for example, Comber cites Cyril of Alexandria in his treatment of the Lord's Prayer. See Comber, A Companion to the Temple, I, p. 135.

${ }^{38}$ Comber, A Companion to the Temple, I, pp. 95-96.

${ }^{39}$ Thus, for example, Comber, A Companion to the Temple, I, pp. 30-32.

${ }^{40}$ Comber, A Companion to the Temple, I, pp. 57-98.

${ }^{41}$ Comber, A Companion to the Temple, I, pp. 36-37.

${ }^{42}$ Comber, A Companion to the Temple, I, pp. 36-37, 331-32.

${ }^{43}$ Comber, Short Discourses, title page.

${ }^{44}$ Thomas Comber, A Companion to the Temple. II. Of the Litany, With the Occasional Prayers and Thanksgivings (Oxford: University Press, 1841), B2.
} 
While Comber rehearses some of the arguments about the lawfulness of set prayers and the prayer book's patristic heritage, these issues are evidently not his focus. Rather, he wishes to provide 'Profitable Meditations' for his readers to 'enlarge upon in their minds' at prayer and so 'put them into a right frame for saying them Affectionately'. ${ }^{45}$ This is not just a matter of the understanding; Comber's reader is to be led to prayerful 'holy meditations' upon the liturgy! ${ }^{46}$

The paraphrase as a lengthy, reflective meditation on the prayer book text is particularly important for Comber. While Comber's verbosity earned him no small amount of criticism from both his contemporaries and modern commentators alike, there was a point to his prolixity. ${ }^{47}$ Bethmont suggests that the structure of Comber's work, moving from 'analytical, learned comments' to 'devotional paraphrase', would indeed 'lead the devout reader from study to meditative prayer', not only later at the public liturgy but in the very act of reading Comber's text! ${ }^{48} \mathrm{He}$ argues that Comber's method here is one typically associated with devotional Bible reading in England in the period, comparing Comber's work to Joseph Hall's Contemplations. ${ }^{49}$ That is, Comber is borrowing a technique associated with meditative reading upon the Bible and applying it to the liturgy! Further, he hopes that his own paraphrases will not only be useful for meditation in their own right but as examples for his readers. He writes that his paraphrases are intended to inspire readers to make 'Pathetical, and pious inlargements [sic]' of their own, the better to make their prayers 'full of life and pleasure'. ${ }^{50}$ Comber's paraphrases are to be a model for his readers as they engage with the liturgy, applying themselves as closely to the liturgy's study as they might to the study of the Bible!

The use of the paraphrase to both explain complicated passages and stir up devotional sentiment was not confined to Comber. Thomas Bennet, after publishing more scholarly books aimed at vindicating the use of set liturgies, turned his attention to a Paraphrase with Annotations upon the Book of Common Prayer, which sought to explain the text, deal with objections, and provide 'Advice ... for promoting true Devotion'. ${ }^{51}$ Bennet forswore the detailed patristic researches of a L'Estrange or Wheatly and did not treat the parts of the prayer book which average laypeople would use infrequently; his preface displays a repeated concern for ease of use for readers for whom an exposition of the ordination service or a discussion of the liturgies of antiquity would be irrelevant. ${ }^{52}$ The book itself was comprised of the headings and rubrics of the prayer book text, with paraphrase of the prayer book

\footnotetext{
${ }^{45}$ Thomas Comber, Short Discourses, A10.

${ }^{46}$ Comber, A Companion to the Temple and Closet, C6.

${ }^{47}$ Shepherd called Comber's works 'both redundant and defective', accusing them of being 'tedious and diffuse'. John Shepherd, A Critical and Practical Elucidation of the Morning and Evening Prayer of the Church of England (London: Printed for F. \& C. Rivington, 1798), p. xlxviii. Stranks calls the works 'laborious and diffuse', and 'not very successful' (Anglican Devotion, p. 157); Horton Davies describes them as 'deadly dull' in Worship and Theology in England. II. From Andrewes to Baxter and Fox, 1603-1690 (Princeton, NJ: Princeton University Pres, 1975), p. 117.

${ }^{48}$ Rémy Bethmont, 'Promoting Anglican Liturgical Spirituality', p. 4.

${ }^{49}$ Bethmont, 'Promoting Anglican Liturgical Spirituality', p. 4.

${ }^{50}$ Comber, A Companion to the Closet and Temple, C7.

${ }^{51}$ Thomas Bennet, A Paraphrase with Annotations upon the Book of Common Prayer (London: Printed for James Knapton, 1709), A3.

${ }^{52}$ Bennet, Paraphrase, A3-A4.
} 
text taking the place of the text of the liturgies proper. Just as in Comber's work, the paraphrases always contain the actual text of the prayer book; the 1709 edition distinguishes them from the paraphrase by means of italics and brackets. While for the daily office Bennet's paraphrases tend to be quite expansive on the devotional model we saw in Comber, his treatment of the Collects and the Holy Communion service is significantly sparer, aimed primarily at elucidating confusing words or phrases. ${ }^{53}$

Another significant example of the paraphrase method is George Stanhope's $A$ Paraphrase and Comment upon All the Epistles and Gospels Appointed to Be Used in the Church of England. As its title suggests, Stanhope's work takes up the Epistles and Gospels appointed for use each Sunday and holy day by the Book of Common Prayer and uses the same paraphrase and commentary techniques we have already seen for the purpose of 'excit[ing] devotion' and 'promot[ing] the knowledge and practice of sincere piety and virtue'. ${ }^{54}$ The format is not dissimilar to the other texts in this category, although it does differ from the earlier paraphrase commentaries in printing the collect and texts for each Sunday or Holy Day separately from the paraphrase. The treatment of St Stephen's Day is typical. The collect is listed first, without analysis. Then follows a brief treatise on the day as a whole, then a paraphrase of the Epistle (with relevant section of the Epistle text printed next to the paraphrase) followed by commentary, and then the same for the Gospel. ${ }^{55} \mathrm{He}$ judges that the texts appointed for public worship are also well suited for 'private study and meditation', as they have been selected both for their comprehensiveness and their comprehensibility. ${ }^{56}$ He specifically enjoins that his text be used devotionally, recommending that 'in the more retired devotions of the family, or of the closet' they be 'made the subject of private consideration, on the respective day of their being publicly read in our churches' ${ }^{57}$ Here the Epistles and Gospels of the church year, as appointed and printed in the Book of Common Prayer, are to structure individuals' and families' devotional engagement with Scripture, eliciting 'edification' and 'good impressions' 58

However, not all devotional works on the prayer book relied on the paraphrase method; Robert Nelson's 1704 A Companion to the Festivals and Fasts of the Church of England used a question-and-answer format to explicate the history and meaning of the various feasts and fasts appointed by the Church of England and enjoin people's keeping of them. ${ }^{59}$ His hope in so doing was to 'contribute something towards reviving the Piety and Devotion of the Primitive Times', adopting a

\footnotetext{
${ }^{53}$ See, for example, Bennet's paraphrase on the Decalogue in the Holy Communion service, which merely clarifies the meaning of the Fourth Commandment, noting that 'hallowed' means 'sanctified' and laying out a basic account of Sabbath duties. Bennet, Paraphrase, p. 160.

${ }^{54}$ George Stanhope, A Paraphrase and Comment upon all the Epistles \& Gospels Appointed to Be Used in the Church of England on all Sundays and Holy-Days Throughout the Year, Vol. 1 (London: Printed for Nunn, Cadell, and Davies, et al., 1817), title page. This is the tenth edition; the first edition listed in the English Short Title Catalogue was printed between 1705 and 1709.

${ }^{55}$ See Stanhope, A Paraphrase and Comment, pp. 197-244.

${ }^{56}$ Stanhope, A Paraphrase and Comment, p. viii.

${ }^{57}$ Stanhope, A Paraphrase and Comment, pp. ix-x.

${ }^{58}$ Stanhope, A Paraphrase and Comment, p. x.

${ }^{59}$ See, for example, his treatment of Whitsunday. Robert Nelson, A Companion upon the Festivals and Fasts of the Church of England (London: Printed for C. \& J. Rivington, J. Nunn et al., 1826), pp. 205-18. Stranks provides a brief publishing history in Anglican Devotion, p. 163.
} 
'catechetical form' because he judges it 'more universally instructive' ${ }^{60}$ While this material generally lacks the meditative devotional quality of Comber or Bennet, the inclusion of prayers at the end of each section does give the work a devotional cast. This is emphasized by Stranks, who argues that the work was intended for 'devotional reading'. ${ }^{61}$ The selection of prayers after the explication of Whitsunday is typical: several prayer book collects, including the collect appointed for the festival; a prayer by an earlier Anglican divine (in this case, a Dr Hickes); and a prayer of Nelson's own composition, which draws heavily on language from the prayer book. ${ }^{62}$ Clearly, Nelson is interested in instilling a devotional life, both for public worship and private devotion, around the prayer book. The focus here is primarily on a devotional life shaped by the prayer book's calendar, but Nelson seeks to bring the prayers of the prayer book into private devotion as well.

In these texts, even more than in the historical or descriptive commentaries, there is a clear attempt to connect devotion with private engagement with the Book of Common Prayer. The authors argue that engagement with the prayer book text as treated by their commentaries will foster a richer experience of public worship, such that these commentaries might be incorporated into one's prayerful preparation for communal worship. Moreover, Bennet and Comber in particular argue that private devotional engagement with the liturgy has value even outside preparation for worship; the prayer book text is well suited, they believe, for the various spiritual needs of Christians. These texts use particular methods, especially the paraphrase, to inspire devotion, making reading the texts themselves an experience which should lead to prayer. In the hands of these authors, the prayer book, mediated through the commentaries they write, becomes central the private spiritual exercises of ordinary Christians.

\section{Annotated Books of Common Prayer}

The works of William Nicholls, the 1707 The Sunday and Holiday Service of the Book of Common Prayer...Paraphrased and the expanded A Commentary on the Book of Common-Prayer, first published in 1710, marked a key innovation in genre for prayer book commentaries. Nicholls' The Sunday and Holiday Service was, according to Griffiths' Bibliography of the Book of Common Prayer, 15491999, the first published annotated Book of Common Prayer. ${ }^{63}$ These books included the prayer book text and added a great variety of devotional and explicatory commentary in its margins. This would become a significant form of prayer book commentary in the eighteenth and well into the nineteenth century, forming part of what Griffiths identifies as an upsurge in unofficial editions of the prayer book during this period. ${ }^{64}$ As time went on, they would prove particularly well suited to the approach we have already seen in Wheatly of combining excerpts from

\footnotetext{
${ }^{60}$ Nelson, A Companion upon the Festivals and Fasts, pp. xix-xx.

${ }^{61}$ Stranks, Anglican Devotion, p. 163.

${ }^{62} \mathrm{Nelson}$, A Companion upon the Festivals and Fasts, pp. 216-18.

${ }^{63}$ William Griffiths, The Bibliography of the Book of Common Prayer, 1549-1999 (London: The British Library, 2002).

${ }^{64}$ Griffiths, Bibliography, p. 14.
} 
earlier writers on the liturgy; this device would serve to codify an accepted tradition of commentators on the liturgy. Given their variety, it is difficult to discern a single attitude towards the devotional use of prayer book materials, but books in this genre clearly expect the prayer book to be engaged with seriously and carefully both in and outside of public worship, and often include commentary with specifically devotional aims in mind.

Nicholls' 1707 Sunday and Holiday Service of the Book of Common Prayer was written specifically for the use of 'Common Persons', who he worries have been ignored in writing on the prayer book, and provides an explanation and devotional guide for the parts of the prayer book used most frequently. ${ }^{65}$ Given Bethmont's argument that the paraphrase technique was associated primarily with Scripture prior to the development of paraphrases on the prayer book, it is worth noting that Nicholls explicitly compares his project to that of scriptural paraphrase. ${ }^{66} \mathrm{He}$ argues that those who might attack his own work as implicitly criticizing the prayer book as difficult to understand would need to reckon with the fact that such criticism could equally be applied to 'all the excellent Labours of those Learned Men who have wrote Comment on the Holy Scriptures'. ${ }^{67}$ This book includes the text of Morning and Evening Prayer, the Litany, the Prayers and Thanksgivings, the Collects (with the Epistles and Gospels listed but not written out), the Holy Communion service, and the Psalter, with each portion of text followed by a quite lengthy paraphrase in smaller print. At times the paraphrase takes up a great deal of space, even whole pages, ${ }^{68}$ but the text was recognizably that of the prayer book, and could conceivably have been used as such ${ }^{69}$ While occasional historical notes were included, Nicholls' aims were evidently primarily explicatory and devotional. ${ }^{70}$

Nicholls' A Commentary on the Book of Common Prayer, first published in 1709, is an expansion of this earlier work, written (according to his Preface) at the behest of 'several Pious ... and some very Learned Persons' who asked him to 'Enlarge the Work'. ${ }^{71}$ Nicholls' Commentary covers the entirety of the Book of Common Prayer rather than just the Sunday services. Further, he seeks to provide significantly more scholarly analysis than in his earlier work, drawing together research on early

\footnotetext{
${ }^{65}$ William Nicholls, The Sunday and Holiday Service of the Book of Common Prayer and Administration of the Sacrament of the Lord's Supper, According to the Use of the Church of England, with the Psalms of David, Paraphrased (London: J. Barber, 1707), A4.

${ }^{66}$ Bethmont, 'Promoting Anglican Liturgical Spirituality', p. 4.

${ }^{67}$ Nicholls, The Sunday and Holiday Service, A7.

${ }^{68}$ See, for example, the commentary on the Exhortation at Morning Prayer on Nicholls, Sunday and Holiday Service, pp. 5-6.

${ }^{69}$ One particularly interesting innovation of Nicholls' work is in the psalter: he omitted the calendar from the front of the prayer book, but provided the daily office lectionary in-line, listing the readings assigned to a given day of the month for each month at the beginning of the portion of the psalter assigned to that day of the month. See, for example, the evening prayer lessons for the second day of the month given in Nicholls, The Sunday and Holiday Service, p. 302. One could either use this to pray morning and evening prayer using Nicholls' book, or at the very least to reference the assigned readings as one reads through the psalms and their paraphrases.

${ }^{70} \mathrm{For}$ an example of a historical note, see the citation of Clement of Alexandria for the antiquity of the Gloria Patri in Nicholls, Sunday and Holiday Service, p. 11.

${ }^{71}$ William Nicholls, A Commentary on the Book of Common-Prayer and Administration of the Sacraments (London: Printed for Bonwicke, Freeman et al., 1712), p. i.
} 
liturgies and on the development of the prayer book itself for those unable to themselves afford 'a Collection of such Books' necessary to show 'the Conformity of the Constitution of their own Church to the Primitive'. ${ }^{72}$ Thus, while he continues to include the text of the prayer book itself and a paraphrase upon it, he adds a section in the body of his work called 'Notes', which are generally of a historical (and specifically patristic) nature, and 'Various Readings', which show variants from the 1662 book in earlier prayer books. ${ }^{73} \mathrm{He}$ also provides an essay on the history of prayer book revision, essays dealing with common objections to the prayer book, publishes liturgical writing by earlier Church of England divines such as John Overall, Lancelot Andrewes, and John Cosin, and appends liturgical material from continental Protestant churches. ${ }^{74}$ It is thanks to this comprehensiveness that Stranks admiringly cites Nicholls' work as 'the fullest collection of Prayer Book material in its day. ${ }^{75}$

While Nicholls' Commentary has significantly loftier scholarly aims than the earlier Sunday and Holiday Service, both are designed not only to vindicate and explain the liturgy of the Church of England but also to be used devotionally. In the preface to the Sunday and Holiday Service, Nicholls writes that he has 'so contriv'd the parts of this paraphrase' that 'they may serve Persons for Forms of Private Devotion', and suggests that this might be best done by rendering plural first person pronouns in the singular as 'I ${ }^{\prime}{ }^{7} \mathrm{He}$ goes on to provide specific advice about the use of devotional material for particular needs: for example, his paraphrase on the Litany would 'not be an improper Form of Devotion upon a day of Fasting', and 'The Paraphrase upon the General Confession, and that upon the Ten Commandments, may very seasonably be used before the receiving of the Sacrament'. ${ }^{77}$ In the preface to his Commentary, Nicholls again stresses that his paraphrases, particularly of Morning and Evening Prayer and the Holy Communion service, were prepared 'not barely for an Explanation of the Text, but that it may serve for a Form of Devotion in their Closets', adding additional advice for occasions on which to use them. ${ }^{78} \mathrm{He}$ admits that a multitude of devotional books already exist. However, he argues that devotions based on the prayer book are particularly helpful because the person using them could be confident that he or she is offering devotions 'warranted . . . by that Church, whereof they are members' rather than using books which may well include questionable elements. ${ }^{79}$ Using devotional materials drawn from approved liturgies will help the Christian avoid what he, referencing

\footnotetext{
${ }^{72}$ Nicholls, A Commentary, pp. i-ii.

${ }^{73}$ For example, a note on Nicholls, A Commentary, p. 115 indicates that the Second Collect at Evening Prayer has its source in the Gregorian Sacramentary, and provides that prayer in Latin, and in his treatment of the Communion service on p. 324 he provides the epicleses of the 1549 Book of Common Prayer and the 1637 Scottish Liturgy under Various Readings.

${ }^{74}$ The essays on the history of the prayer book and answering common objections to it are found at the end of Volume I of Nicholls' Commentary; the liturgical material from continental Protestant churches can be found in Volume II, pp. 280-98. Addleshaw notes that Cosin's notes were first published in Nicholls' Commentary on Addleshaw, The High Church Tradition, p. 31.

${ }^{75}$ Stranks, Anglican Devotion, p. 161.

${ }^{76}$ Nicholls, Sunday and Holiday Service, A11.

${ }^{77}$ Nicholls, Sunday and Holiday Service, A11.

${ }^{78}$ Nicholls, A Commentary, p. ii.

${ }^{79}$ Nicholls, A Commentary, p. ii.
} 
Lev. 10.1 and the rejected offering of Aaron's sons, calls 'offer[ing] strange fire unto the Lord'. 80

One of the most important developments in the tradition of annotated versions of the Book of Common Prayer after Nicholls' work was an emphasis on compiling and excerpting the work of earlier prayer book commentators. John Fludger's 1739 A Correct and Familiar Exposition of the Book of Common Prayer Collected from the Works of Bishop Sparrow, Bishop Andrews [sic], Bishop Beveridge, Bishop Pearson, Doctor Comber, Doctor Nichols, Doctor Biss, and Other Divines and Fernandino Warner's 1754 An Illustration of the Book of Common Prayer... in which the Observations of all the Learned Divines, who have wrote upon any Part of it, are inserted and included in their proper Course, with Further explanations by the Compiler are both good examples of the genre. As these titles suggest, both draw upon earlier sources to annotate the text of the Book of Common Prayer with both historical and expository notes and extensive paraphrase. Fludger describes his project as creating 'a faithful extract from so many Comments, reduced to only one single volume in Folio'; whereas Warner describes his as a modest revision of Nicholl's Commentary which removes excessive prolixity and supplies lacking information by recourse to other earlier commentators, contemporary ones, or Warner himself. ${ }^{81}$ Fludger does not see fit to cite the source of a given note or paraphrase, but a look at the beginning of Morning Prayer shows a quite creative process of compilation: he provides an introduction to the service, with the first paragraph taken from Sparrow and the second from Comber, and then includes paraphrases on the opening sentences also taken from Comber. ${ }^{82}$ Warner, thankfully for the scholar, does more regularly cite sources; he draws primarily on Nicholls while including a broader commentary tradition. ${ }^{83}$ While neither of these compilers emphasizes his work as devotional in its own right, they clearly expect in-depth individual engagement with the prayer book and its commentary tradition. Warner in particular emphasizes that it is 'a matter of the utmost Consequence in the Worship of God, that everyone should be able to Pray with the Understanding', and released his work in portions to minimize cost so that it could be read by the 'Common People' who Warner saw as his primary audience. ${ }^{84}$

Warner makes an offhand remark in his Advertisement that his Illustration could be used as 'a most excellent Family-Book', which provides a helpful entry point into another subgenre of annotated prayer book: annotated books of common prayer

\footnotetext{
${ }^{80}$ Nicholls, A Commentary, p. ii.

${ }^{81}$ John Fludger, A Correct and Familiar Exposition of the Book of Common Prayer Collected from the Works of Bishop Sparrow, Bishop Andrews [sic], Bishop Beveridge, Bishop Pearson, Doctor Comber, Doctor Nichols, Doctor Biss, and Other Divines (London: Thomas Gardner, 1739), p. i; Fernandino Warner, An Illustration of the Book of Common Prayer and Administration of the Sacraments and other Rites and Ceremonies of the Church of England in which the Observations of all the Learned Divines, who have wrote upon any Part of it, are inserted and included in their proper Course, with Further explanations by the Compiler (London: Printed for John Allan and James Hodges, 1754), pp. 1-2.

${ }^{82}$ Fludger, A Correct and Familiar Exposition, pp. 3-4.

${ }^{83}$ See, for example, the treatment of the Opening Sentences and Exhortation at morning prayer in Warner, An Illustration of the Book of Common Prayer, pp. 60-62; uncited material is typically taken from Nicholls.

${ }^{84}$ Warner, An Illustration of the Book of Common Prayer, p. 1.
} 
clearly designed for individual or family devotional use. ${ }^{85}$ Likely influenced by the emphasis on family prayer in eighteenth-century England, ${ }^{86}$ several annotations emerged during this period called Family Prayer Books, designed explicitly for family devotion ${ }^{87}$ others had titles that suggest individual devotion like The Christian's Companion.$^{88}$ These annotated prayer books often had additional devotional material bound up with them, such as family prayers or preparations to receive communion, mostly commonly a work called A Companion to the Altar which existed in several versions. ${ }^{89}$ These individual or family prayer books were written with an intent to spur devotion in public worship, but they often include advice for using the prayer book in private or family devotions and incorporate additional material for devotional use. For sake of space, this essay will focus on a few representative books of this variety.

There were three different annotated prayer books called family prayer books produced during the period studied: Andrew Johnson's 1775 The Complete Family Prayer Book, James Cookson's 1783 A New Family Prayer-Book, and Paul Wright's 1785 The New and Complete Family Prayer-Book. Each of these included the text of the prayer book with commentary and the sacramental guide $A$ Companion to the Altar; Johnson and Wright also included a form of family prayers. Wright's subtitle, declaring that his book was written 'to excite Devotion, and enable one to Pray with the Understanding' describes the purpose of all of these books quite well. ${ }^{90}$ Cookson's annotations are relatively minimal, and primarily explicatory in nature, while both Johnson and Wright have considerably more extensive notes, including the use of paraphrase for at least part of the prayer book. They largely draw on the same set of liturgical commentators this essay has already examined; Wright enumerates a lengthy list of sources consulted including Sparrow, Wheatly, Comber, Bennet, Warner, L'Estrange, and Beveridge. ${ }^{91}$ Indeed, it is hard not to notice a degree of repetitiveness in these works: all three of them, for example, quote Nicholls (without citing him) in explaining the three parts of the absolution at Morning Prayer. ${ }^{92}$ The most obviously devotional material in these sorts of books

\footnotetext{
${ }^{85}$ Warner, An Illustration of the Book of Common Prayer, p. 1.

${ }^{86}$ See Andrew Braddock, 'Domestic Devotion and the Georgian Church', Journal of Anglican Studies 16.2 (2017), pp. 188-206 and W.M. Jacob, “Conscientious Attention to Publick and Family Worship of God": Religious Practice in Eighteenth-Century English Households', Studies in Church History 50 (2014), pp. 30717 for good overviews of the current state of research on domestic devotion during the period, and especially note the profusion of literature for domestic devotion.

${ }^{87}$ Andrew Johnson, The Complete Family Prayer Book (London: Printed for R. Snagg, 1775); James Cookson, A New Family Prayer-Book (Winchester: J. Wilkes, 1783); Paul Wright, The New and Complete Family Prayer-Book (London: Printed for Alex Hogg, 1785).

${ }^{88}$ The Christian's Companion, or the Book of Common Prayer (Birmingham: James Belcher, 1790); A Christian's Universal Companion (Gainsbrough: J. Mozeley, 1778); The Christian's Useful Companion (Birmingham: Robert Martin, 1776).

${ }^{89}$ See Robert Wright, Prayer Book Spirituality (New York: The Church Hymnal Corporation, 1989). Note that ordinary prayer books of this period often also were bound with additional devotional material when printed, as noted in Griffiths, Bibliography, p. 44.

${ }^{90}$ Wright, The New and Complete Family Prayer-Book, title page.

${ }^{91}$ Wright, The New and Complete Family Prayer-Book, title page.

${ }^{92}$ Johnson, The Complete Family Prayer Book, pp. 50-51; Cookson, A New Family Prayer-Book, pp. 42-43; Wright, The New and Complete Family Prayer-Book, p. 11 for the treatment of the absolution; Nicholls, Commentary.
} 
are appended sacramental guides and family prayers. These did not invariably include prayer book material - indeed, the family prayers in Wright and Johnson do not - but sometimes did make creative use of them..$^{93}$ Of course, the very titles 'Family Prayer Book' or 'Christian's Companion' suggests that these volumes, and the prayer book they contain, should have a place in family and individual devotion. Cookson makes this particularly explicit by expressing skepticism at the practice of 'compiling forms of private devotion' since the Book of Common Prayer 'will answer every purpose of private worship and prayer. ${ }^{94}$ Like Nicholls, Cookson believes that the Book of Common Prayer is not only acceptable for use in private devotion but preferable for it; it can, he believes, rightly meet all spiritual needs of Church of England Christians!

In the annotated prayer books, we see the full development of the process of tradition-formation already evident in Wheatly's Rationale. The practice of annotating prayer books with explanations drawn not only from the author or editor of a given annotation but from a canon of liturgical commentators worked to cement the very identity and boundaries of that canon. Furthermore, in these texts, we continue to see an emphasis on encouraging a deeper devotional engagement with the prayer book. Not only are these texts written with the aim of inspiring deeper devotion in public worship, but they teach and model devotional engagement with the prayer book texts for private devotional needs as well. The annotations are given not just to elucidate the prayer book text but, in some cases, to be forms of prayer in their own right. Indeed, both Nicholls and Cookson argue that the prayer book and devotions based upon it are the best forms of private devotional literature!

\section{Conclusion: Making Prayer Book People}

In 1820, Richard Mant published The Book of Common Prayer... with Notes Practical, Explanatory, and Historical, from Approved Writers of the Church of England. This work would prove, in retrospect, the high-water mark of the prayer book commentary tradition of the long eighteenth century. Mant produced a nowfamiliar genre of text: the Book of Common Prayer itself, annotated with abundant notes drawn from the commentary tradition we have been exploring. Indeed, the list of authors consulted provides a good orientation to this tradition as a whole. ${ }^{95}$ Of course, it is not that writing on the prayer book or even specific methods such as the annotated Book of Common Prayer disappeared after Mant. Nearly fifty years later, John Blunt would publish his celebrated The Annotated Book of Common Prayer. ${ }^{96}$ However, a comparison between Mant's sources and Blunt's is telling: Nicholls, that mainstay of eighteenth-century annotated prayer books, does not appear at all in

\footnotetext{
${ }^{93}$ Thus, for example, the family prayers at the end of The Christian's Universal Companion both includes collects taken directly from the prayer book and prayers expanding on prayer book language, such as the morning prayer of thanksgiving, which begins with the first words of the General Thanksgiving: 'Almighty God, Father of all mercies...'. See The Christian's Universal Companion, p. 408.

${ }^{94}$ Cookson, A New Family Prayer-Book, p. viii.

${ }^{95}$ Richard Mant, The Book of Common Prayer and the Administration of the Sacraments According to the Use of the United Church of England and Ireland with Notes Explanatory, Practical, and Historical, from Approved Writers of the Church of England (Oxford: Baxter, 1825), pp. ix-x.

${ }^{96}$ John Henry Blunt, The Annotated Book of Common Prayer (London: Rivingtons, 1867).
} 
Blunt's list! ${ }^{97}$ Moreover, while mentioning many of the older divines, Blunt expresses particular allegiance to the new, more critical historical liturgical research of Palmer and Maskell and also includes the writings of Oxford Movement writers with a less celebratory attitude towards the prayer book. ${ }^{98}$ Indeed, Braddock calls 1833 and 1834 the 'high tide of traditional Prayer Book defence', after which Tractarians and their successors 'increasingly rejected the traditional arguments used in defence of the prayer book', held up the 1549 prayer book and especially its Holy Communion service as preferable to the 1662, and condemned the earlier commentary tradition as 'unscholarly and inadequate'. ${ }^{99}$ The golden age of the Book of Common Prayer and the golden age of the prayer book commentary tradition I have traced ended at about the same time.

This essay has been sought to excavate this largely ignored tradition of writing on the Book of Common Prayer in order to explore the role the Book of Common Prayer played in private devotion as well as public worship. As we have seen, the works of this tradition frequently encouraged close study of the text and the use of the prayer book in private prayer, and often explicitly described increasing devotion in the use of the prayer book in its users as their aim. Indeed, some texts were comprised of devotional meditations in their own right. The pre-Civil War tradition of defending the prayer book exemplified by Hooker, Whitgift, and Boys was taken up and extended in a set of historical and expository commentaries on the prayer book such as those of Sparrow and Wheatly, which encouraged individual engagement with the liturgy and, in some cases, private prayer using it. Another genre of commentaries, exemplified by the voluminous work of Thomas Comber, had more explicitly devotional aims. The third significant type of long-eighteenth-century prayer book commentary was the annotated prayer book, inaugurated by the work of William Nicholls. The text of the prayer book itself was printed with notes and paraphrases designed to explain, justify, and encourage devotion, often excerpted from previous writers on the prayer book. As it developed from Nicholls to Mant, this genre allowed for the articulation of a prayer book commentary tradition as commentators selected from what became a canon of approved writers from whom to excerpt material.

While these books were never published in the numbers of the Restoration Church's most popular devotional work, Richard Allestree's The Whole Duty of Man, or indeed the Book of Common Prayer itself, we have evidence of their significance both on their own and as part of a broader argument for the private use of the prayer book. ${ }^{100}$ To provide a few examples, the English Short Title Catalogue

\footnotetext{
${ }^{97}$ Blunt, The Annotated Book of Common Prayer, pp. xi-xiv.

${ }^{98}$ See Blunt, The Annotated Book of Common Prayer, pp. v-vi for a discussion of Maskell and Palmer and the older commentary tradition; and pp. xi-xiv for a list of authorities consulted. Unsurprisingly given his use of Oxford Movement sources, Blunt is particularly concerned to maintain continuity between the preand post-Reformation English Church, which he argues that Wheatly, Comber and their compatriots utterly failed to do. Braddock provides a helpful treatment of Palmer on Braddock, The Role of the Book of Common Prayer, pp. 62-64.

${ }^{99}$ Braddock, The Role of the Book of Common Prayer, pp. 118-19. As Braddock notes, even Palmer came to be seen as too sympathetic to the prayer books of 1552 and following!

${ }^{100}$ See C. John Sommerville, Popular Religion in Restoration England (Gainesville, FL: University Presses of Florida, 1977), p. 38. The English Short Title Catalogue lists a whopping 175 printings of The Whole Duty of Man between its publication in 1657 and 1800 .
} 
lists 14 printings of Sparrow's Rationale and 11 printings of Wheatly's Rational Illustration before 1800. Nicholl's prayer book commentary went through nine printings by 1775 , and was still being published a century after its first edition. ${ }^{101}$ Cookson's Family Prayer-Book was in its fourth edition by 1789. ${ }^{102}$ Mant's commentary was printed multiple times, seeing four editions within the first decade of publishing. ${ }^{103}$ Even Comber's massive multi-volume commentary saw multiple printings, with each volume reprinted between three and five times, and the English Short Title Catalogue lists 13 printings of his shorter A Companion to the Temple. ${ }^{104}$ Given how frequently works in the commentary genre drew on each other, it is worth adding that the influence of a given author often extended beyond the printings of their particular works.

Further, the commentary tradition was just one of the textual ways in which the clergy of the Church of England in the long eighteenth century sought to encourage private engagement with the prayer book. The aforementioned popular devotional text The Whole Duty of Man, for example, instructed readers to pray Morning and Evening Prayer out of the prayer book with their families. ${ }^{105}$ Moreover, there were a plethora of devotional pamphlets which compiled useful collects or simplified daily prayer services out of the Book of Common Prayer or included devotions which used prayer book language. ${ }^{106}$ To give one example out of many, the 100-page long tract, The Common Prayer-Book the Best Companion in the House and Closet, as Well as in the Temple, initially published in 1686, was in its 22nd (and final) edition in $1762 .{ }^{107}$ The commentary tradition joined other printed texts as well as nonprinted sermons or other forms of instruction to argue that the prayer book could and should shape the devotional lives of English Christians both at public worship and in private devotion. Yet if the commentary tradition was not the only way that members of the Church of England were encouraged to engage privately with the liturgy, these texts' comprehensiveness and detail give us a valuable look at the methods and arguments used to justify and teach the private use of the prayer book.

As we have seen, commentators argued for the appropriateness of praying the daily office alone or with one's family, if one cannot attend daily public worship, and advocated for careful study of the prayer book as a means of enlivening one's devotion in public worship. They also suggested that the prayer book was particularly well suited for private devotion as a safely approved text which contains material for every spiritual need. They provided extensive aids for devotional engagement with the prayer book, especially paraphrases but also additional prayers and meditations and advice for finding prayer book material, especially collects, pertinent to specific topics. In all these ways, the commentary tradition sought to form prayer

\footnotetext{
${ }^{101}$ See the English Short Title Catalogue and Griffiths, Bibliography, p. 224.

${ }^{102}$ Griffiths, Bibliography, p. 201.

${ }^{103}$ Griffiths, Bibliography, p. 266.

${ }^{104}$ See here Bethmont, 'Promoting Anglican Liturgical Spirituality', p. 8.

${ }^{105}$ The Whole Duty of Man (London: Printed for C. \& J. Rivington, 1828), pp. 86-87. Jacobs, 'Religious Practice', p. 311 discusses its popularity.

${ }^{106}$ Braddock discusses this in 'Domestic Devotion', p. 192.

${ }^{107}$ See the English Short Title Catalogue. The Common Prayer-Book the Best Companion in the House and Closet, as Well as in the Temple (London: Printed for J. Fuller, J. Richardson, B. Davey, B. Law, and B. Staples, 1753).
} 
book people, Christians who went to the authorized liturgy of the church not only for public worship, nor even only for private preparation for public worship, but for a whole host of their spiritual needs. The Collect appointed in the 1662 Book of Common Prayer for the Second Sunday in Advent petitioned God to 'grant that' the congregation might 'hear ... read, mark, learn, and inwardly digest' the Scriptures; the central devotional message of the prayer book commentary tradition was that the exact same sort of practice might rightly be applied to the prayer book itself. $^{108}$

\footnotetext{
${ }^{108}$ The Book of Common Prayer and Administration of the Sacraments and other Rites and Ceremonies of the Church According to the Use of the Church of England (Cambridge: Cambridge University Press, 2004), p. 49.

Cite this article: Crosby, B. (2023). Read, Mark, Learn and Inwardly Digest: The Prayer Book and Private Devotion in Prayer Book Commentaries from Sparrow to Mant. Journal of Anglican Studies 21, 87-105. https://doi.org/10.1017/S1740355321000504
} 